\title{
HANTAVIRUS PULMONARY SYNDROME IN NORTHWESTERN ARGENTINA: CIRCULATION OF LAGUNA NEGRA VIRUS ASSOCIATED WITH CALOMYS CALLOSUS
}

\author{
SILVANA LEVIS, JORGE GARCIA, NOEMÍ PINI, GLADYS CALDERÓN, JOSEFINA RAMÍREZ, DANIEL BRAVO, \\ STEPHEN ST. JEOR, CARLOS RIPOLL, MARIANA BEGO, ELENA LOZANO, RUBÉN BARQUEZ, \\ THOMAS G. KSIAZEK, AND DELIA ENRIA \\ Instituto Nacional de Enfermedades Virales Humanas Dr. Julio I. Maiztegui, Pergamino, Argentina; Hospital San Miguel, \\ Yuto, Jujuy, Argentina; Hospital Oscar Orías, Libertador Gral. San Martín, Jujuy, Argentina; Department of Microbiology, \\ University of Nevada, Reno, Nevada; Dirección de Epidemiología, Jujuy, Argentina; Fundación Miguel Lillo, Tucuman, Argentina; \\ Special Pathogens Branch, Centers for Disease Control and Prevention, Atlanta, Georgia
}

\begin{abstract}
The purpose of this study was to characterize the hantaviruses circulating in northwestern Argentina. Human and rodent studies were conducted in Yuto, where most cases of hantavirus pulmonary syndrome (HPS) occur. Partial virus genome sequences were obtained from the blood of 12 cases of HPS, and from the lungs of 4 Calomys callosus and 1 Akodon simulator. Phylogenetic analysis showed that three genotypes associated with HPS circulate in Yuto. Laguna Negra (LN) virus, associated with C. laucha in Paraguay, was identified for the first time in Argentina; it was recovered from human cases and from $C$. callosus samples. The high sequence identity between human and rodent samples implicated $C$. callosus as the primary rodent reservoir for LN virus in Yuto. The genetic analysis showed that the Argentinian LN virus variant differed $16.8 \%$ at the nucleotide level and $2.9 \%$ at the protein level relative to the Paraguayan LN virus. The other two hantavirus lineages identified were the previously known Bermejo and Orán viruses.
\end{abstract}

\section{INTRODUCTION}

Hantaviruses are rodent-borne viruses that belong to the genus Hantavirus of the family Bunyaviridae. ${ }^{1}$ The hantaviruses have tripartite, single-stranded RNA genomes. The small (S) genomic segment encodes the nucleocapsid (N) protein; the medium (M) genomic segment encodes the glycoproteins $\mathrm{G} 1$ and $\mathrm{G} 2$, and the large (L) genomic segment encodes the viral RNA-dependent RNA polymerase. ${ }^{2}$ After the identification of Sin Nombre (SN) virus in 1993, many other hantaviruses have been identified in the Americas. Hantavirus pulmonary syndrome (HPS) is a public health problem of increasing significance, especially in South America, where an increasing number of HPS cases are reported each year. ${ }^{3,4}$ Among the hantaviruses known to cause HPS in South America are Juquitiba (JUQ), ${ }^{5}$ Araraquara (ARA), and Castelo dos Sonhos (CAS) viruses from Brazil, ${ }^{6}$ and Laguna Negra (LN) virus from Paraguay and Bolivia. ${ }^{7}$ Rio Mamore (RM) virus from Bolivia and Caño Delgadito virus from Venezuela have been detected in the rodent species Oryzomys microtis and Sigmodon alstoni, respectively, but have not yet been linked to HPS. ${ }^{8-10}$ In Argentina, seven different genotypes of hantaviruses have been identified. Four of them have been associated with human disease and include Andes (AND) virus in the southwestern provinces of Rio Negro, Chubut and Neuquén, ${ }^{11}$ Lechiguanas (LEC) and Hu39694 viruses in the central Buenos Aires and Santa Fe Provinces, and Orán (ORN) virus in northwestern Salta Province. ${ }^{12,13}$ The primary rodent hosts for AND and ORN virus genotypes is Oligoryzomys longicaudatus; while LEC and Hu39694 virus genotypes have been found in $O$. flavescens. Three other virus genotypes have also been recognized: Maciel (MAC), Pergamino (PGM), and Bermejo (BMJ) viruses, ${ }^{12-14}$ MAC and PGM viruses have been identified from Necromys benefactus and Akodon azarae from central Argentina, respectively; while BMJ virus genotype was originally recovered only from a single $O$. chacoensis captured near Orán. All of these hantaviruses are hosted by rodents of the family Murinae, subfamily Sigmodontinae.
In the hantavirus-endemic area of northwestern Argentina, hantavirus disease was first diagnosed in 1994 in the subtropical region of Orán, in which HPS case-patients were associated with viruses of the ORN genotype. After the recognition of the disease in the neighboring province of Jujuy in 1997, an increasing number of HPS cases were prospectively diagnosed by enzyme-linked immunosorbent assay (ELISA). The largest number of HPS cases diagnosed in Jujuy Province originated in Ledesma Department $(74.6 \%, 53$ of 71$)$; the main focus was located in the rural town of Yuto, with $62.3 \%$ (33 of 53) of the HPS cases recorded in this department (Ripoll $\mathrm{C}$, unpublished data). Interestingly, a higher incidence of human hantavirus infection and a generally less severe clinical form of HPS has been observed in this location (Pini $\mathrm{N}$ and others, unpublished data and Ripoll $\mathrm{C}$, unpublished data). This finding is different from the epidemiology of HPS in the rest of the hantavirus-endemic areas of Argentina. To determine the genetic diversity of hantaviruses causing HPS in northwestern Argentina, we studied the genetic types of hantaviruses found in human and rodent samples from this region.

\section{MATERIALS AND METHODS}

Rodent samples. Rodent trapping was conducted at nine sites in Yuto and the surrounding area, both at the presumed sites of infection for known HPS case-patients and in nearby natural habitats, in May 2000 (Pini N and others, unpublished data). Lung tissues from hantavirus antibody-positive rodents (seven Calomys callosus and four Akodon simulator) were examined following reverse transcription (RT) and amplification by polymerase chain reaction $(\mathrm{PCR})$ in a nested assay. ${ }^{15}$ The PCR products were sequenced.

Patient samples. Human blood clots from serologically confirmed cases of acute HPS from Yuto and other locations of Jujuy Province were used as source for virus RNA extraction. Samples sent for clinical diagnosis followed the ethical procedures of the local hospital where patients were assisted. 
The protocol studies conducted in Yuto and surrounding areas were reviewed and approved by the institutional ethical review committee (Comité de Evaluación Ética de Investigaciones Biomédicas del Instituto Nacional de Enfermedades Virales Humanas).

Isolation of total RNA, RT-PCR, and sequence analysis. Total RNA was extracted from the lungs of hantavirus antibody-positive rodents and blood clots of hantavirus antibody-positive human by using the RNaid (PLUS) kit (Bio 101 Inc., La Jolla, CA). Amplification of virus RNA was done by a RT-PCR, followed by a nested PCR amplification as described previously. ${ }^{15}$ The DNA product of the nested PCR was excised after electrophoresis from an agarose gel, and bands of the predicted size were purified from gels slices using a GeneClean kit (Bio 101 Inc.). The nucleotide sequences of these products were determined by the automatic dydeoxy cycle sequencing technique (Applied Biosystems, Foster City, CA). ${ }^{3}$ Oligonucleotides primers were designed based on predicted virus-conserved sequence regions to amplify fragments of $\mathrm{M}$ genome segment glycoprotein-encoding region of Argentinian hantavirus genotypes and LN virus from Paraguay. Primers were designed to amplify fragments of the $\mathrm{N}$ protein of the $\mathrm{S}$ segment on the basis of conserved hantavirus sequences obtained from the GenBank database including LN virus, AF005727; AND virus strain AH-1, AF324901; ARA virus, AF AF307325; BMJ virus, AF482713; LEC virus, AF482714; ORN virus, AF482715; and PGM virus, AF482717. 7,12 Extended sequence analysis was done with primers designed based on sequence data obtained in this study. Sequences were aligned with those of previously described hantaviruses using BioEdit version 5.0.6 (North Carolina State University, Raleigh, NC) and the computer software package Clustal W $1.4,{ }^{16}$ followed by manual adjustment based on deduced amino acid sequences.
Phylogenetic analysis. Phylogenetic analysis was carried out on the multiple nucleotide (partial S and $\mathrm{M}$ genome segments) and amino acid (partial M-G2 genome segment) sequence alignments by using maximum parsimony (Phylogenetic Analysis Using Parsimony [PAUP] version 4.0b4a Macintosh computer software programs). ${ }^{17}$ Phylogenetic analysis by maximum parsimony was obtained by the heuristic search method. The bootstrap support for the results of the phylogenetic analysis was based on 500 replicates.

\section{RESULTS}

Genetic characterization of virus strains. RNA was extracted from available lung tissues of 10 hantavirus antibodypositive rodents (six C. callosus and four A. simulator) and blood clots from 14 HPS case-patients from Yuto and other locations in the Ledesma Department of Jujuy Province (Figure 1). Primers used were designed to amplify partial fragments of the $\mathrm{N}$ protein gene of the $\mathrm{S}$ genome segment, and the G1 and G2 glycoprotein-encoding regions of the $\mathrm{M}$ genome segment. Nested RT-PCR products of the expected size (273 nucleotides) for the $\mathrm{S}$ segment were obtained from five hantavirus antibody-positive rodents, and from 12 HPS cases. Hantavirus M-G1 and M-G2 segment cDNAs fragments (328 and 256 nucleotides, respectively) were amplified from seven patient clots, using a set of primers designed to detect Argentinian hantavirus $\mathrm{M}$ segment sequences. All attempts to amplify $\mathrm{M}$ segment pieces from $A$. simulator and $C$. callosus hantavirus antibody-positive samples, as well as from samples from the remaining seven HPS case-patients using the same sets of primers, failed.

Because of the close geographic relationship between Yuto, Bolivia, and Paraguay, an M-specific set of primers based on sequences of LN virus was designed for the PCR

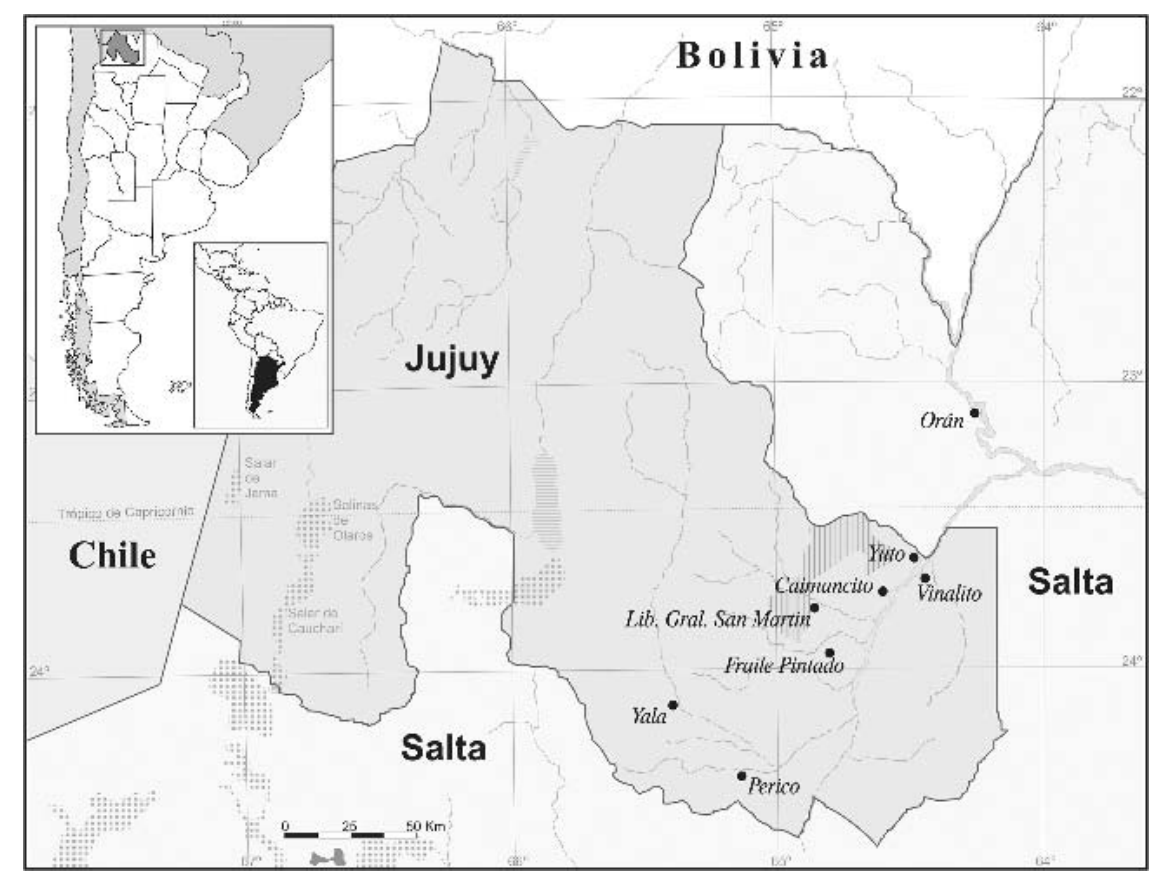

Figure 1. Jujuy Province in Argentina and localities of the origin of cases of hantavirus pulmonary syndrome and rodents positive for antibodies to hantavirus antibody selected for polymerase chain reaction analysis. 
analysis of these rodent and human samples. Products of the expected size were obtained from one $A$. simulator, four C. callosus, and five HPS case-patients. Further amplification using newly designed specific primers based on rodent and HPS case sequences was obtained. The phylogenetic analysis of nucleotide sequence differences in these three regions showed the circulation of three hantavirus lineages causing HPS in the limited geographic area studied. The ORN genotype, previously described from human HPS cases and from O. longicaudatus from the nearby location of Orán in Salta province, ${ }^{12}$ was recovered from six HPS cases from Yuto. In pairwise comparisons against the nucleotide sequence of the homologous region of previously characterized hantaviruses, the 273-nucleotide sequence of S genome segment exhibited 95.6-98.5\% nucleotide identity with the ORN genotype from Salta. A similar pattern was seen with the G2 and G1 fragments of the $\mathrm{M}$ segment, showing an identity of $93.7-99.6 \%$ nucleotides and 92.3-94.2\% nucleotides, respectively, when compared with ORN virus.

The second genotype identified was BMJ, previously described from a single $O$. chacoensis from Orán in Salta Province $^{12}$; the virus sequence showed a $82.8 \%, 95.7 \%$, and $94.2 \%$ nucleotide sequence identity in 273-, 328-, and 256-nucleotide fragments from the S, M-G1, and M-G2 genome segments, respectively, when compared with the virus sequence from one $O$. chacoensis from Salta province. This represents the first demonstration that BMJ virus is associated with HPS in Argentina. Finally, LN virus was recovered for the first time in Argentina from HPS cases and rodent samples. Comparison of the nucleotide sequences detected in five HPS cases, four $C$. callosus, and one A. simulator showed $83.6-84.2 \%$, $80.2-85.1 \%$, and $81.2-82.0 \%$ nucleotide sequence identity for the S, and M-G1, and M-G2 genome fragments, respectively, when compared with the LN virus from Paraguay. Mean sequence variation among the LN virus detected in the human and rodent samples was $0.6 \%, 2.7 \%$, and $0.9 \%$ for the S, M-G1, and M-G2 genome segment fragments, respectively.

Phylogenetic analysis. The phylogenetic analysis based on the M-G1 genome segment-encoding region using maximum parsimony (Figure 2) showed that all samples from C. callosus, one A. simulator, and 5 HPS case samples fell into the LN lineage group; 6 HPS case samples fell into the ORN genetic group, and only one sample from an HPS patient grouped with BMJ virus. The nodes separating $\mathrm{LN}, \mathrm{ORN}$, and BMJ lineages had bootstraps values of $99 \%, 95 \%$, and $99 \%$, respectively; however, the exact branching order of the Argentinian hantaviruses relative to other South American lineages can not be resolved by the present phylogenetic analysis. ARA virus (host unknown) from Brazil is placed together with MAC virus (Akondontini-borne virus) from central Argentina, although with a low (52\%) bootstrap support. A 1,371-nucleotide sequence of the M-G2 genome segment was generated from one representative strain of each of the three hantavirus lineages detected in Yuto. The phylogenetic tree showed a similar topology to the one obtained on the M-G1 genome segment fragment. The three hantavirus lineages (LN, ORN, and BMJ) are positioned together with the other South American hantaviruses, forming a well supported clade (90\%) (Figure 3); the nodes separating these lineages had bootstrap values of $100 \%, 60 \%$, and $97 \%$, respectively. The genetic analysis showed that the $\mathrm{LN}$ virus variant recovered

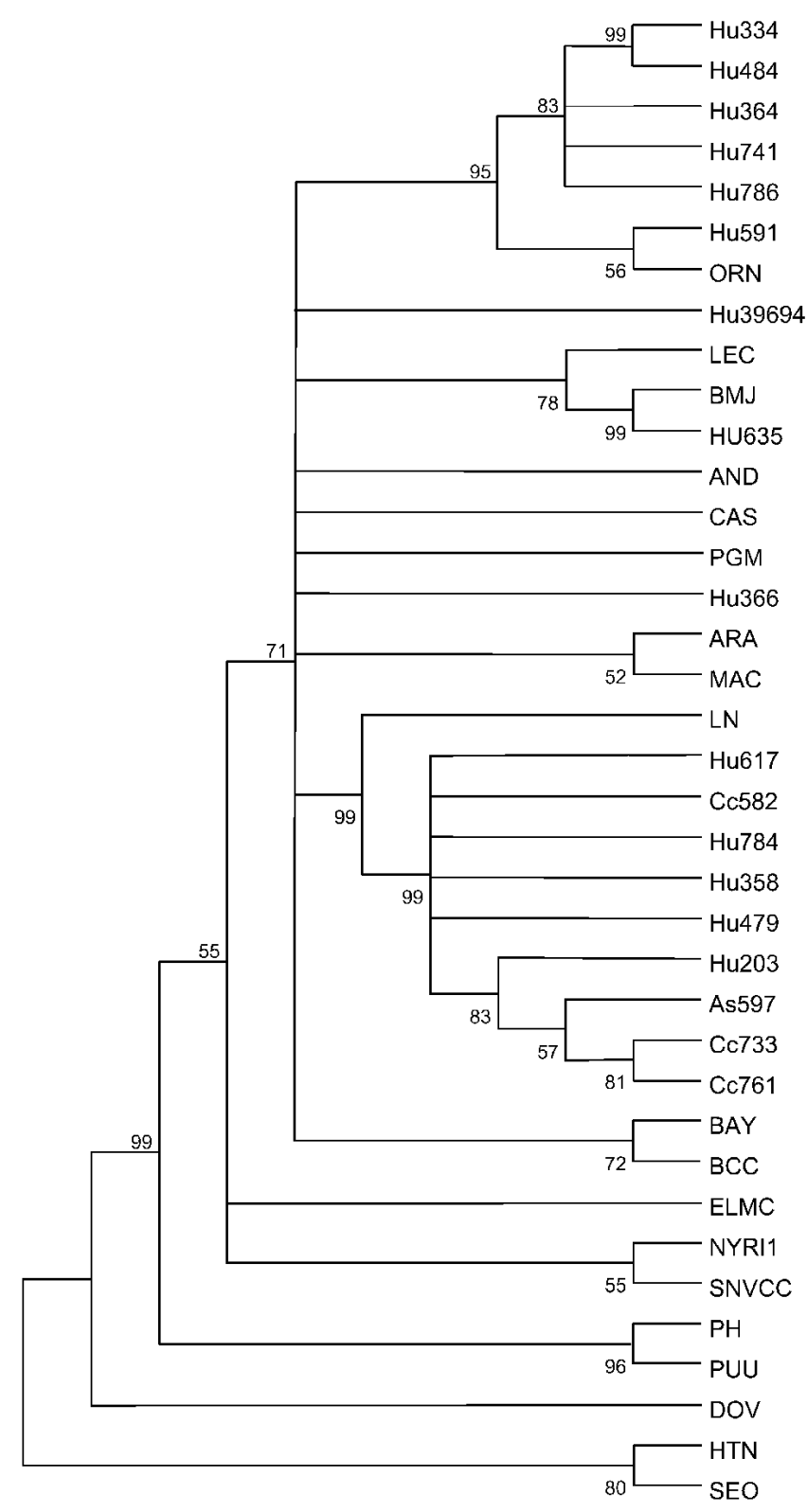

FIGURE 2. Phylogenetic tree inferred by maximun parsimony analysis of a 258-nucleotide fragment of the medium-glycoprotein 1 (M-G1) genome segment of Laguna Negra (LN), Orán (ORN), and Bermejo (BMJ) viruses derived from rodents and hantavirus pulmonary syndrome case samples from Yuto, Argentina and other previously characterized hantaviruses. The third base position was removed from the analysis. Bootstrap confidence limits were calculated by using 500 repetitions of analysis; values $>50 \%$ are indicated at branch points. Vertical branches are for visual purposes only. M segment sequences with the following GenBank accession numbers were used in this study: Andes (AND) AH-1, AF324901; Araraquara (ARA) AF307327; Bayou (BAY) L36930; BMJ strain Oc2253, AF028025; Castelo dos Sonhos (CAS) AF307326; Hantaan (HTN) 76-118, Y00386; Hu39694, AF028023; Lechiguanas (LEC) strain Of22819, AF028022; LN AF005728; Maciel (MAC) strain Bo13796, AF028027; Oran strain Ol22996, AF028024; Pergamino (PGM) strain Aa14403, AF028028; Prospect Hill (PH) X55129; Puumala (PUU) Sotkamo strain, X61034; Seoul (SEO) strain SR-11, M34881; Sin Nombre (SNV) CC74, L33684. Cc = Calomys callosus; As = Akodon simulator $; \mathrm{BCC}=$ Black Creek Canal; $\mathrm{ELMC}=\mathrm{El}$ Moro Canyon; NYR = New York hantavirus, strain Rhode Island 1; DOV = Dobrava virus. 


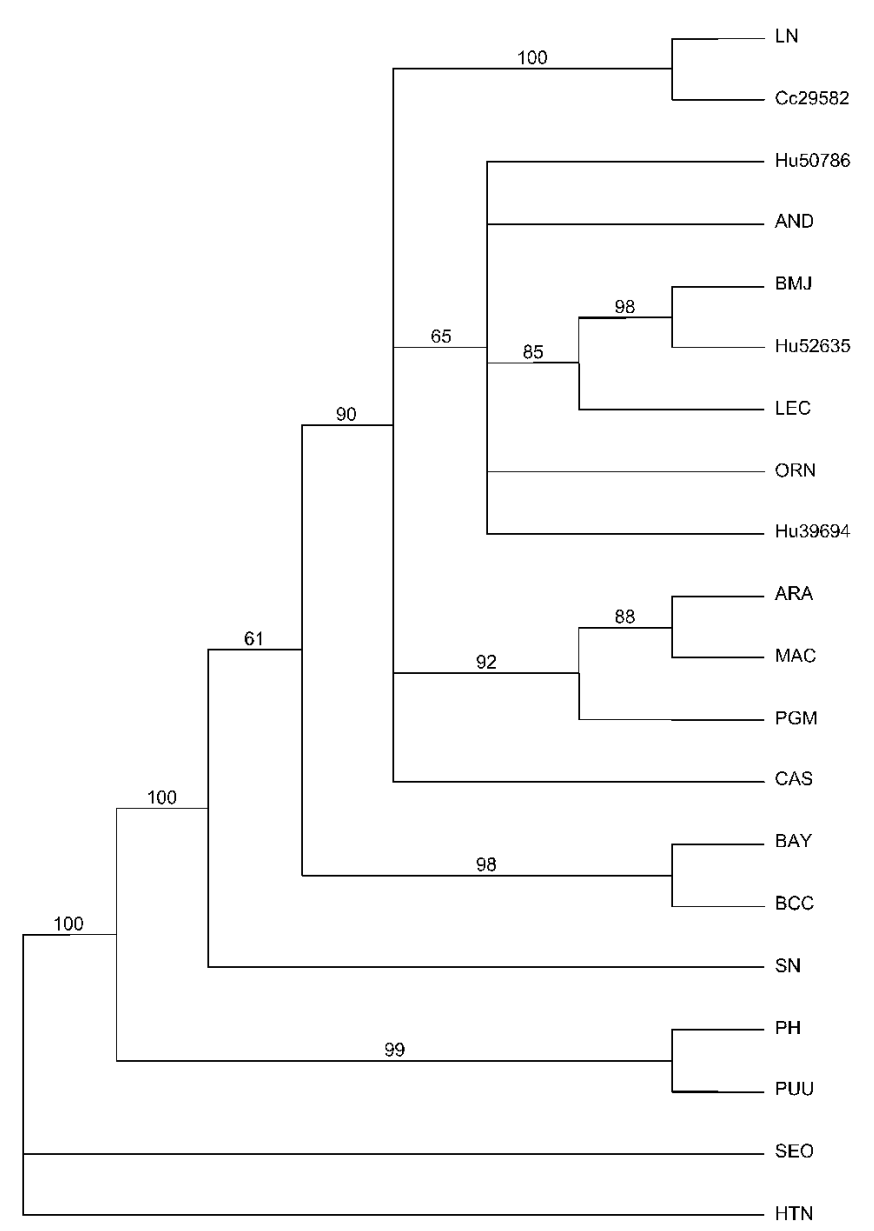

FIGURE 3. Phylogenetic tree inferred by maximun parsimony analysis of a 1,371-nucleotide fragment of M-G2 sequences of a representative strain of Orán (ORN), and Bermejo (BMJ) viruses derived from hantavirus pulmonary syndrome case samples, and Laguna Negra (LN) virus derived from Calomys callosus samples from Yuto, Argentian and other previously characterized hantaviruses. The third base position was removed from the analysis. Bootstrap confidence limits were calculated by using 500 repetitions of analysis; values $>50 \%$ are indicated at branch points. Vertical branches are for visual purposes only. For M segment sequence GenBank accession numbers used in this study and definitions of abbreviations, see Figure 2.

from C. callosus (sample Cc29582) differed $16.8 \%$ at the nucleotide level and $2.9 \%$ at the deduced amino acid level relative to the Paraguayan $\mathrm{LN}$ virus; while representative virus strains of ORN (sample Hu50786) and BMJ (sample Hu52635) lineages, showed 7.6\%, 4.3\% nucleotide differences and $1.1 \%,-0.5 \%$ amino acid differences relative to the prototype ORN and BMJ viruses, respectively.

\section{DISCUSSION}

After the confirmation in 1994 of HPS in northwestern Argentina (Orán in Salta Province), intensive surveillance activities were conducted in the region. In 1997, the neighboring province of Jujuy had its first indigenous HPS cases. Most of cases in this province have originated in or around the town of Yuto. A particular epidemiologic pattern characterized the HPS cases in this area, with a high incidence of illness (1.46/
10,000 inhabitants), and a low case-fatality rate $(12.76 \%)$ associated with a higher percentage of milder illness (Ripoll C, unpublished data). In our serologic studies of rodents captured in Yuto (Pini $\mathrm{N}$ and others, unpublished data), we found that the two most frequently trapped sigmodontine rodent species, $C$. callosus and $A$. simulator, were positive for antibodies to hantavirus; neither of these species had previously been associated with human hantavirus infections.

To identify the hantavirus(es) causing HPS in Jujuy Province, PCR amplification and sequencing of the appropriate PCR product was conducted in blood samples from seropositive HPS cases and rodent samples. Phylogenetic analysis of $\mathrm{M}$ and $\mathrm{S}$ genome fragments indicated a high genetic diversity of hantaviruses associated with HPS in the limited geographic area of Yuto: the circulation of three previously known hantaviruses (the Paraguayan LN virus, ORN virus, and BMJ virus) was documented. Phylogenetic analysis based on the sequence data of virus genome fragments of the S, M-G1, and M-G2 segments showed that the LN virus lineage, associated with C. laucha (vesper mouse) in Paraguay, ${ }^{7}$ was associated with $C$. callosus rodents and HPS cases from the same area of Yuto (more than $600 \mathrm{~km}$ from the area in Paraguay where the virus was described). The high sequence identity between human and rodent samples (>97.3\% nucleotide and $100.0 \%$ amino acid) implicated C. callosus as the primary rodent reservoir for LN virus circulating in Yuto. Our rodent trapping data indicated that $C$. callosus, as well as $A$. simulator, were the most abundant rodent species captured in the area (137 of $327,38.0 \%$ and 140 of $327,39 \%$ ); however, C. callosus exhibited the highest prevalence of antibody to hantavirus (7 of $137,5.1 \%)$. These observations correlate with one of the criteria currently accepted in identifying a primary rodent species as a primary rodent host for hantaviruses. ${ }^{18}$ The phylogenetic analysis places LN virus from Paraguay and Yuto together, with a $100 \%$ bootstrap support.

The fact that LN virus strains in Paraguay and Argentina (difference between them of $16.8 \%$ nucleotides and $2.9 \%$ amino acids) are associated with different species of the same rodent genus (C. laucha and C. callosus, respectively), suggests the coevolutionary relationship between the viruses and that of the corresponding primarily associated rodent reservoirs. Similarly, examples of a pattern of co-speciation was observed in North American rodent genus Peromyscus: SN-like viruses are associated to genetically distinct $P$. $m a$ niculatus and P. leucopus. ${ }^{18-20}$ Our sequence data also indicated that a LN virus strain was derived from one $A$. simulator. Although the serologic data indicated that there were four positive $A$. simulator by ELISA, we detected virus sequences using the RT-PCR only in one of them. This could represent a $\mathrm{LN}$ virus spillover infection from the primary rodent host $C$. callosus into A. simulator. The pattern of unique hantavirus infection of a primary rodent host includes the chronic infection of the primary rodent reservoir species, as shown by the ability to consistently amplify hantavirus sequences from serologically positive rodents. Conversely, spillover infections are usually charaterized by acute infection with subsequent clearance of virus. ${ }^{18}$ Thus, the possibility of an spillover from $C$. callosus into $A$. simulator cannot be excluded.

The other two genotypes recovered from HPS cases were the previously characterized Oligoryzomys-borne BMJ and 
ORN viruses. ${ }^{12}$ The recovery of a BMJ viral genotype from one fatal HPS case from Yuto constitutes the first evidence of its pathogenicity in Argentina; it was previously known only from one $O$. chacoensis in Orán. However, its association with human disease was predictable because the phylogenetic analysis had grouped the BMJ viral genotype into the subclade of the Oligoryzomys-borne viruses, most of them associated with HPS in Argentina. A recent report described the association of the BMJ viral genotype to HPS cases in Bolivia. ${ }^{14}$ The Oran virus genotype remains the most frequent cause of HPS, while previous studies showed that it was the main cause of HPS near Orán. ${ }^{12}$ Our sequence data identified ORN virus genotype in $50 \%$ (6 of 12) of the human samples that were positive by RT-PCR. Curiously, the high frequency of ORN virus genotype sequences in human case-patient samples does not correlate with low abundance of the rodent species that serves as its putative reservoir $(3.3 \%$ of the total captures) or the lack of detectable hantavirus antibody prevalence among rodents from the genus Oligoryzomys. It must be pointed out that our rodent data correspond to a unique rodent capture study conducted in Yuto in 2000, while HPS case-patient samples included in the present study comprised a four-year period (1998-2001). Moreover, only two of six ORN viral genotype sequences were identified in human case-patient samples from Yuto; the remaining four ORN viral sequences came from HPS cases from Caimancito, Perico and Fraile Pintado, locations where no rodent trapping was conducted. As rodent community diversity is influenced by temporal, ecologic, and environmental factors, more intensive rodent serologic surveys in the region would serve to clarify this point.

Interestingly, one of the major differences in rodent behavior observed between Oligoryzomys and Calomys species is the relative capacity of $C$. callosus to invade human dwellings. Calomys callosus was the only wild rodent species captured inside houses in Yuto (Pini $\mathrm{N}$ and others, unpublished data), a fact that increases the potential exposure of humans to infected rodents. This also correlates with previous observations in Bolivian hemorrhagic fever outbreaks, caused by Machupo virus, which is harbored by $C$. callosus in Bolivia. ${ }^{21} \mathrm{On}$ the other hand, a serologic and epidemiologic survey conducted in healthy people from Yuto (Pini N and others, unpublished data) simultaneously with our rodent trapping found one of the highest prevalences $(6.5 \%)$ of antibody to hantavirus in the general population found in Argentina. These data correlate with previous observations from serologic surveys conducted in healthy communities of the Gran Chaco of Paraguay and Argentina (Salta Province) in which hantavirus antibody prevalences of $20-40 \%$ had been found. ${ }^{7,22,23}$ Moreover, the particular epidemiologic pattern of higher incidence of human infection, low case-fatality rate $(12.7 \%)$, and less clinical severity in this area would support the hypothesis that a less virulent hantaviruses may be circulating in the region under study. The fact that the two fatal cases were associated with Oligoryzomys-borne ORN and $\mathrm{BMJ}$ virus genotypes, while none was observed associated to LN virus might suggest that $\mathrm{LN}$ virus could be at least one of the viruses associated with a milder and/or inapparent form of infection in this region. Further ongoing comparative studies on the clinical pattern of infection associated with the different hantavirus lineages circulating in Jujuy will help to clarify this point.
Received August 5, 2003. Accepted for publication July 15, 2004.

Acknowledgments: We thank Dr. S. Morzunov and Dr. John Boone for critical review of the manuscript; Verónica Fasciani for technical assistance; and Horacio López, Germán O’Duyer, Cesar Polidoro, Enrique Serrrano, Miguel Canchi, Alberto Segobia, Julio Gil, Bernardino Perez, Monica Diaz, and David Flores for their technical field work.

Financial support: This research was supported by the Administración Nacional de Laboratorios e Institutos de Salud (ANLIS), Ministerio de Salud Pública de la Nación, Argentina; Ministerio de Salud Pública de la Provincia de Buenos Aires, Argentina; and National Institutes of Health grant 1R01 AI-45059.

Authors' addresses: Silvana Levis, Jorge Garcia, Noemí Pini, Gladys Calderón, and Delia Enria, Instituto Nacional de Enfermedades Virales Humanas Dr. Julio I. Maiztegui, Monteagudo 2510, 2700 Pergamino, Buenos Aires, Argentina, Telephone: 54-2477-433044, Fax: 54-2477-433045, E-mail: inevh@satlink.com. Josefina Ramírez and Elena Lozano, Hospital San Miguel, 4518 Yuto, Jujuy, Argentina, Telephone 54-3886-498015. Daniel Bravo, Hospital Oscar Orías, San Martin 66, 4512 Libertador Gral. San Martín, Jujuy, Argentina, Telephone 54-3886-42728. Stephen St. Jeor and Mariana Bego, Department of Microbiology, Howard Building 320, Room 146, University of Nevada, Reno, NV 89557, Telephone: 702-784-6161, Fax: 702784-1620, E-mail: stjeor@med.unr.edu. Carlos Ripoll, Dirección de Epidemiología, San Martin 41, 4600 San Salvador de Jujuy, Jujuy, Argentina, Telephone 54-388-4221300. Rubén Barquez, Fundación Miguel Lillo, M. Lillo 205, 4000 Tucumán, Argentina, Telephone 54-381-4330888. Thomas G. Ksiazek, Special Pathogens Branch, Centers for Disease Control and Prevention, 1600 Clifton Road, Atlanta, GA 30333, Telephone: 404-371-5329, Fax: 404-371-5449.

Reprint requests: Silvana Levis, Instituto Nacional de Enfermedades Virales Humanas Dr. Julio I. Maiztegui, Monteagudo 2510, 2700 Pergamino, Buenos Aires, Argentina.

\section{REFERENCES}

1. Schmaljohn CS, Hasty SE, Dalrymple JM, LeDuc JW, Lee HW, von Bonsdorff $\mathrm{CH}$, Brummer-Korvenkontio M, Vaheri A, Tsai TF, Regnery HL, Doldgaber D, Lee PW, 1985. Antigenic and genetic properties of viruses linked to haemorrhagic fever with renal syndrome into a newly defined genus of Bunyaviridae. Science 227: 1041-1044.

2. Elliott RM, 1990. Molecular biology of the Bunyaviridae. J Gen Virol 71: 501-502.

3. Nichol ST, Spiropoulou CF, Morzunov S, Rollin PE, Ksiazek TG, Feldmann H, Sanchez A, Childs G, Zaki S, Peters CJ, 1993. Genetic identification of a hantavirus associated with an outbreak of acute respiratory illness. Science 262: 914-917.

4. Peters CJ, 1998. Hantavirus pulmonary syndrome in the Americas. Scheld WM, Craig WA, Hughes JM, eds. Emerging Infections 2. Washington, DC: American Society for Microbiology Press, 17-64.

5. da Silva MV, Vasconcelos MJ, Hidalgo NTR, Veiga APR, Canzian M, Marotto PC, de Lima VC, 1997. Hantavirus pulmonary syndrome. Report of the first three cases in São Paulo, Brazil. Rev Inst Med Trop Sao Paulo 39: 231-234.

6. Johnson AM, De Souza LTM, Ferreira IB, Pereira LE, Ksiaszek TG, Rollin PE, Peters CJ, Nichol ST, 1999. Genetic investigation of novel hantaviruses causing fatal HPS in Brazil. J Med Virol 59: 527-535.

7. Johnson AM, Bowen MD, Ksiazek TG, Williams RJ, Bryan RT, Mills JN, Peters CJ, Nichol ST, 1997. Laguna Negra virus associated with HPS in western Paraguay and Bolivia. Virology 238: 115-127.

8. Bharadwaj M, Botten J, Torrez-Martinez N, Hjelle B, 1997. Rio Mamore virus: genetic characterization of a newly recognized hantavirus of the pygmy rice rat (Oligoryzomys microtis) from Bolivia. Am J Trop Med Hyg 57: 368-374.

9. Hjelle B, Torrez-Martinez N, Koster FT, 1996. Hantavirus pulmonary syndrome-related virus from Bolivia (letter). Lancet 347: 57 . 
10. Fulhorst CF, Monroe MC, Salas RA, Duno G, Utrara A, Ksiazek TG, Nichol ST, de Manzione NMC, Tovar D, Tesh RB, 1997. Isolation, characterization, and geographic distribution of Caño Delgadito virus, a newly discovered South American hantavirus (family Bunyaviridae). Virus Res 51: 159-171.

11. López N, Padula P, Rossi C, Lázaro ME, Franze-Fernández MT, 1996. Genetic identification of a new hantavirus causing severe pulmonary syndrome in Argentina. Virology 220: 223-226.

12. Levis SC, Morzunov SP, Rowe JE, Enría DA, Pini N, Calderón G, Sabattini M, St. Jeor SC, 1998. Genetic diversity and epidemiology of hantaviruses in Argentina. J Infect Dis 177: 529538.

13. Levis S, Rowe J, Morzunov S, Enria DA, St Jeor S, 1997. New hantaviruses causing hantavirus pulmonary syndrome in central Argentina. Lancet 349: 998-999.

14. Padula P, González Della Valle M, Garcia Alai M, Cortada P, Villagra M, Gianella A, 2002. Andes virus and first case report of Bermejo virus causing fatal pulmonary syndrome. Emerg InfectDis 8: 437-439.

15. Spiropoulou CF, Morzunov S, Feldmann H, Sanchez A, Peters CJ, Nichol ST, 1994. Genome structure and variability of a virus causing hantavirus pulmonary syndrome. Virology 200: 715-723.

16. Thompson JD, Higgins DG, Gibson TJ, 1994. CLUSTAL W: Improving the sensitivity of progressive multiple sequence alignment through sequence weighting, position-specific gap penaltiens and weight matrix choices. Nucleic Acids Res 22: 4673-4680.
17. Swofford, DL, 2000. PAUP*: Phylogenetic Analysis Using Parsimony (and Other Methods). Version 4.0b4a. Sunderland, MA: Sinauer Associates, Inc.

18. Plyusnin A, Morzunov SP, 2001. Virus evolution and genetic diversity of hantaviruses and their rodent hosts. Curr Top Microbiol Immunol 256: 47-75.

19. Morzunov SP, Rowe JE, Monroe MC, Ksiazek TG, Peters CJ, St.Jeor SC, Nichol ST, 1998. Genetic analysis of the diversity and origin of hantaviruses in Peromyscus leucopus mice in North America. J Virol 72: 57-64.

20. Monroe MC, Morzunov S, Jhonson AM, Bowen MD, Artsob M, Yates T, Peters CJ, Rollin PE, Ksiazek TG, Nichol ST, 1999. Genetic diversity and distribution of Peromyscus-borne hantaviruses. Emerg Infect Dis 5: 75-86.

21. Kuns ML, 1965. Epidemiology of Machupo virus infection. II. Ecological and control studies of hemorrhagic fever. $\mathrm{Am}$ J Trop Med Hyg 14: 813-816.

22. Ferrer JF, Jonsson C, Esteban E, Galligan D, Basombrio MA, Peralta-Ramos M, Bharadwaj M, Torres-Martínez N, Callahan J, Segovia A, Hjelle B, 1998. High prevalence of hantavirus infection in Indian comunities of the Paraguayan and Argentinean Gran Chaco. Am J Trop Med Hyg 59: 438444.

23. Williams RJ, Bryan RT, Mills JN, Palma RE, Vera I, Velásquez F, Baez EM, Schmidt WE, Figueroa RE, Peters CJ, Zaki SR, Khan AS, Ksiazek TG, 1997. An outbreak of hantavirus pulmonary syndrome in western Paraguay. Am J Trop Med Hyg 57: $274-282$. 